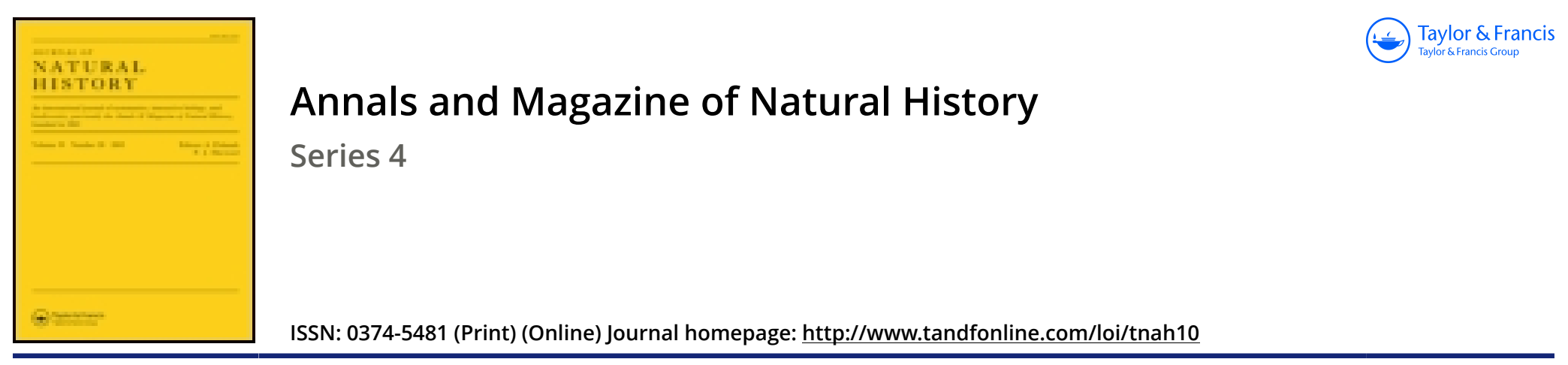

\title{
Vl.-Note on lists of Arctic Hydroida and Polyzoa published in the 'Annals' for February 1874 and January 1877
}

\section{Rev. Thomas Hincks B.A. F.R.S.}

To cite this article: Rev. Thomas Hincks B.A. F.R.S. (1877) VI.--Note on lists of Arctic Hydroida and Polyzoa published in the 'Annals' for February 1874 and January 1877, Annals and Magazine of Natural History, 20:115, 66-67, DOI: 10.1080/00222937708682192

To link to this article: http://dx.doi.org/10.1080/00222937708682192

曲 Published online: 13 Oct 2009.

Submit your article to this journal $\pi$

Џ Article views: 1

Q View related articles $₫$ 
Coll. Hart: Cape Fraser, 20 fathoms, one female specimen.

The specimens collected of this very remarkable species, which has been fully described and illustrated by the late Dr. M. Sars in the memoir above referred to, are unfortunately all much mutilated; in none are the antennæ and slender and greatly elongated legs of the third and fourth pairs in a perfect condition.

The largest specimen, the female from Cape Fraser, has the ovigerous plates greatly developed, and is about $9 \frac{1}{2}$ lines (18 millims.) long.

This species has been found at a depth of 50-100 fathoms in the Christiania Sound, and at a depth of 250 fathoms at the Lofoten Islands. It is also recorded by Buchholz (Crust. in ' Zweite deutsche Nordpolarf.' p. 285, note) from Spitzbergen, and was obtained during the cruise of the 'Valorous,' in lat. $69^{\circ} 31^{\prime} \mathrm{N}$., long. $56^{\circ} 1^{\prime}$ W., at a depth of 100 fathoms.

[To be continued.]

VI.-Note on Lists of Arctic Hydroida and Polyzoa published in the 'Annals' for February 1874 and January 1877 *. By the Rev. Thomas Hincks, B.A., F.R.S.

IN the first of the papers referred to above $I$ have given an account of some Hydroids which were obtained by Dr. Wallich, as I supposed, off the coast of Iceland. In the second some Polyzoa which formed part of the same gathering were catalogued and several new species described.

The bottle containing the dredging, which was placed in my hands by Mr. Busk, was labelled legibly, "Off Reykjavik, in 100 fathoms, amongst icebergs grounded and drifting," or to this effect; and $I$ had no reason whatever to suspect inaccuracy. Since the publication of the second paper, however, Dr. Wallich, whose attention had not been previously directed to the matter, has informed me that there has undoubtedly been some blunder, inasmuch as there is no water of the depth off Reykjavik, nor are there any icebergs $\dagger$. He has kindly examined his journals, notes, \&c. for the purpose of removing, if possible, the doubt as to the locality; and his conclusion is that the material with which $I$ have dealt in $\mathrm{my}$

* "On Deep-water Hydroida from Iceland," Annals, Feb. 1874,p. 146 ; "On Polyzoa from Iceland and Labrador," Annals, Jan. 1877, p.97.

$\dagger$ Dr. Wallich writes (in litt.), "At Rekiavik Harbour I dredged not from the ship, but from a boat. In no part of the harbour did I find deeper water than about 20 fathoms. I do not believe there is much deeper water within half a mile of the little town; and beyond this range I did not go. The harbour is a bay in no sense comparable to a fiord, the shore being sloping, and flat, low islands scattered here and there. A berg could not get into the harbour. Even outside the mouth of the bay, southward of Cape Rekianess, no icebergs are ever in these days met with." 
papers was obtained off Frederickshaab, Davis Straits, in 100 fathoms, and amongst bergs grounded and drifting, as stated on the label. How the name Reykjavik came to tind its way into the place which should have been occupied by the name Frederickshaab it is impossible to say with certainty. As in other cases Dr. Wallich appears to have written on his labels the date, with the depth and other particulars, but without the name of the place, it is possible he may have done so in the present instance, and that when the bottle was made over to Mr. Busk the wrong name may have been inserted by mistake. However this may be, there can be no doubt, I think, that the Hydroida and Polyzoa which I have catalogued and described are Greenlandic and not Icelandic. All the evidence points in this direction. The date on the bottle containing them is that of Dr. Wallich's visit to Frederickshaab, where he dredged once amongst icebergs, in 100 fathoms. The label exactly resembles one that was attached to undoubted Frederickshaab specimens, in all but the name of the place, bearing the same particulars, written in the same fashion, on the same kind of paper, and in partially faded ink. Dr. Wallich's recollection also favours this view. $\mathrm{He}$ distinctly remembers that in the single haul off Frederickshaab a large quantity of plant-like Hydroids came up; and they actually formed the chief element of the contents of the bottle that passed into my hands.

On the whole there seems to be little room for doubt; and I must beg those who may refer to my papers for the locality to credit the species recorded in them to Frederickshaab instead of to Reykjavik.

While dredging in Reykjavik Harbour, Dr. Wallich took up a small quantity of Hydroida \&c. in 15-20 fathoms, which he has been good enough to send me for examination; and I am thus enabled to publish a short list of undoubted Icelandic species.

\section{Hydroida and Polyzoa from Reykjavik Harbour.}

Campanularia volubilis, Linn.

Calycella syringa, Limn.

Lafoëa grandis, Hincks.

quadridentata, Hincks.

Filellum serpens, $W$. Thomson.

Sertularella polyzonias, Linn., var. gigantea.

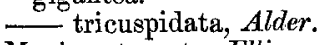

Menipea ternata, Ellis and Sol.
Scrupocellaria scabra, Van Ben.

Caberea Ellisii, Fleming.

Membranipora lineata, Linn.

Lepralia trispinosa, Johnston, var.

- hyalina, Limn.

Cellepora plicata, Smitt.

Crisia eburneo-denticulata, Smitt.

Idmonea atlantica, $\boldsymbol{E}$. Forbes.

Discoporella verrucaria, $F a b r$.

All the species here recorded were also taken at Frederickshaab. 